\title{
What is a university for?: the rise and fall of developmental higher education in Africa
}

\section{Miles Larmer}

\section{University of Oxford}

At the heart of Tim Livsey's ground-breaking new study is the question: what is a university for? Academics often take for granted their own vision of a university, as an open space for ideas and free thinking, and assume it is held universally. But it is clear that for states, donors and indeed many if not most students, universities have more prosaic or personal functions. For many of the first generation of students at the University of Ibadan, as at other new universities in decolonising countries, it provided a path to individual as well as collective advancement, either entrenching the existing privileges of elites or providing a fast track to power and privilege for poorer entrants. For all such students, Livsey's work demonstrates, their individual hopes often fused with their hopes for their new nation-to-be, investing their aspirations with a powerful legitimising patriotic veneer. Academics zealously guarded their universities against actual or perceived political 'interference' but also used the university as a space to advance their own political agenda. Administrators sought to ensure the autonomy of their universities, but equally sought funding from external agencies such as western donors and the Ford or Rockefeller Foundation, each of which had, unsurprisingly, its own agenda for higher education in Africa. Politicians saw universities both as personal projects linked to their own vision for national advancement, or more prosaically as utilitarian organisations to provide skills necessary for modernisation.

One of the book's clearest insights is to reveal both the degree and variety of contestation over what a university fit for a new nation would look like and how to ensure that it would be both equal to its western counterparts and meaningfully African and/or Nigerian. Arguments over this found expression in the allocation of funding and in the design of curricula, but also in the recruitment of faculty, the design of university buildings and campuses, and - as Livsey shows - in the more informal cultural practices therein.

And this is why defining the University of Ibadan and the wider Nigerian university programme in the late colonial and early independence period as a 'development' project, as Livsey does, is an inspired masterstroke. Indeed, I was initially sceptical about this characterisation, firstly because my conventional view of a late-colonial development project is more infrastructural, concrete and prosaic than my own definition of a university. If Livsey had used development in that way, then I don't think the study would have worked so well: but in fact his sophisticated use of the concept builds on the work of e.g. Stephan Miescher (2014) in his analysis of the Volta project in Ghana, where the Akosombo Dam is simultaneously a literal concrete edifice and an ideational project into which incompatible aspirations for different kinds of advancement were invested. As Livsey demonstrates, universities are a no more predictable stimulus to the achievement of 'development' than large-scale dams have proven to be.

As a historian of central Africa I was interested in the comparison between the University of Ibadan, known across the continent as a globally significant seat of learning, and some of its counterparts elsewhere. The University of Zambia, for example, which opened shortly after independence in 1964, was funded in part by a popular fundraising campaign to which thousands of ordinary Zambians contributed - including those who had little schooling themselves but who saw in the 
university a symbol of their hopes both for independence and for their own children. In its early days, UNZA, like Ibadan, looked like and was initially experienced as an elite space, with silver cutlery, waiters at dinner and so forth. Its first students saw themselves as being trained for political leadership, and thus were among the first Zambians to clash with the new post-independence ruling elite when they sought to advance their political ideas (Larmer, 2016: 68-9). In this sense, universities are spaces in which inter-generational encounters and conflicts are central to historical and political change in Africa and beyond. Livsey's study is part of a growing set of histories of African universities: for example, Dan Hodgkinson's work (2013) on the University of Zimbabwe or Pedro Monaville (2013) on the Congolese student movement, studies which explore the attempts of a first 'born free' generation to make their Eurocentric institutions relevant to themselves and their societies. Livsey's book and the work of these other researchers resonate in instructive ways with today's struggles to decolonise and Africanise universities in Africa and beyond, including my own institution, the University of Oxford.

What has changed of course, between the heyday of the 1960s and today is the standard of living and the societal position of most students in Africa's universities: when I first visited UNZA In the early 1990s, students were living in squalid overcrowded dorms and some were sleeping on the roofs of buildings: they were politically active, not with the confidence of a future generation of leaders but rather with a more subaltern sense of frustrated aspirations. As Leo Zeilig (2008) has argued for Zimbabwean students, the downward mobility of university students may lead them to identify with the wider urban poor. Whether and in what circumstances universities engage with wider dynamics of social, cultural and political change, requires as always more research in this area, and in this respect Tim Livsey has provided an important stimulus in considering how to think about not only the African university, but also the university writ large .

\section{References}

Hodgkinson, Dan. 2013. 'The 'Hardcore' Student Activist: The Zimbabwe National Students Union (ZINASU), State Violence, and Frustrated Masculinity, 2000-2008'. Journal of Southern African Studies, 39, (4): 863-883.

Larmer, Miles. 2016 [2011]. Rethinking African Politics: A History of Opposition in Zambia. Abingdon: Routledge.

Miescher, Stephan. 2014. 'Nkrumah's Baby: the Akosombo Dam and the dream of development in Ghana, 1952-1966'. Water History 6 (4): 341-366. 
Monaville, Pedro. 2013. 'Decolonizing the University: Postal Politics, The Student Movement, and Global 1968 in the Congo' PhD thesis, University of Michigan.

Zeilig, Leo. 2008. 'Student Politics and Activism in Zimbabwe: The Frustrated Transition'. Journal of Asian and African Studies 43 (2): 215-237. 